\title{
Influence of Leadership Style, Career Development, and Work Satisfaction on Employee Performance In Tropical Disease Institutions of Airlangga University Surabaya
}

\author{
Mahendra Fredyantono Rahadytya ${ }^{\mathrm{a}^{*}}$, and Hermien Tridayanti ${ }^{\mathrm{b}}$ \\ ${ }^{a}$ Faculty of Economics anda Business, Narotama University Surabaya, Indonesia, mfredyantono@gmail.com \\ ${ }^{b}$ Faculty of Economics anda Business, Narotama University Surabaya, Indonesia, hermien.tridayanti@narotama.ac.id
}

\begin{abstract}
This study aims to determine and analyze the Leadership Style, Career Development, and Job Satisfaction simultaneously and significantly to Employee Performance. This research is qualitative research. The population and sample based on the distribution of questionnaires to employees of the Surabaya Tropical Disease Institute were taken as many as 59 respondents. Data collection techniques using interviews, observation, and questionnaires. Analysis of the data used is the reliability test, validity test, classic assumption test, and multiple linear analysis test. The results of the study simultaneously and partially Leadership Style, Career Development, and Job Satisfaction have a positive and significant effect on employee performance. The F test result is 16.703 greater than the 2.00 table simultaneously. Partially the Leadership Style obtained a significant value of 0,000 (less than 0.05) significant effect on employee performance, Career Development obtained a significant value of 0.025 (less than 0.05) significant effect on employee performance, and Job Satisfaction obtained significant value of 0.049 (less than 0.05) has a significant effect on employee performance.
\end{abstract}

Keywords: Leadership Style, Career Development, Job Satisfaction, and Employee Performance

\section{Introduction}

HR is also a key that determines the development of the company. In essence, human resources in the form of people employed in an organization as a mobilizer, thinker and planner to achieve the goals of the organization. The Institute for Tropical Diseases has tasks such as developing, developing and managing tropical disease research, organizing information dissemination on health science and public welfare services in the field of tropical diseases.

The Institute for Tropical Diseases, Airlangga University, Surabaya is doing an innovation or development. Therefore, employees are required to provide maximum performance. Therefore, leaders who have the right leadership style are needed so that they are able to influence employees to provide the best performance for the achievement of company goals. According to (Thoha, 2010) stated that leadership style is the norm of behavior used by someone when the person is trying to influence the behavior of others or subordinates.

Look at the phenomena that occur at the Institute of Tropical Diseases, which are currently in an effort to develop Human Resources. In order for employees to work more optimally, companies need to manage their careers and develop them well so that employee productivity is maintained and able to encourage employees to do the best so that it leads to an increase in company performance and the achievement of company goals.

The last factor identified affects employee performance, which is employee job satisfaction. The definition of job satisfaction according to (Badriyah, 2015b) is the attitude or feeling of employees towards pleasant or unpleasant aspects of funding work in accordance with the assessment of each employee.

\footnotetext{
* Corresponding author.

E-mail address: mfredyantono@gmail.com (Mahendra Fredyantono Rahadytya)
} 
Therefore, based on the description above, the author is interested in conducting a study entitled "The Effect of Leadership Style, Career Development, and Job Satisfaction on Employee Performance, Studies on Employees of the Tropical Disease Institute of Airlangga University, Surabaya".

Based on the background description described earlier, the formulation of the problem in this study is.

1. Does the leadership style have a significant effect partially on the performance of TDC Airlangga employees?

2. Does career development have a partially significant effect on the performance of Unair TDC employees?

3. Does job satisfaction have a partially significant effect on the performance of Unair TDC employees?

4. Does the leadership style, career development, and job satisfaction simultaneously have a significant effect?

\section{Theoretical framework}

(Badriyah, 2013)Human resources are one of the important factors in development. At a macro level, development input factors, such as natural resources, materials, and finance will not provide optimal benefits for improving people's welfare without being supported by adequate human resource factors, both in quality and quantity.

According to (Thoha, 2010) stated that leadership style is the norm of behavior used by someone when the person is trying to influence the behavior of others or subordinates. Determining the right leadership style can create good relations between leaders and subordinates, this will certainly affect the performance of employees.

According to(Ardana et al., 2012) career development is a personal improvement done by someone to achieve a career plan and improvement by the personnel department to achieve a work plan in accordance with the path or level of the organization.

(Badriyah, 2015a) Job satisfaction is one of the most important factors to get optimal work results. When someone feels satisfaction at work, he will make every effort possible with all the ability he has to complete his work assignments. Thus, productivity and performance results will increase optimally.

\section{Conceptual framework}

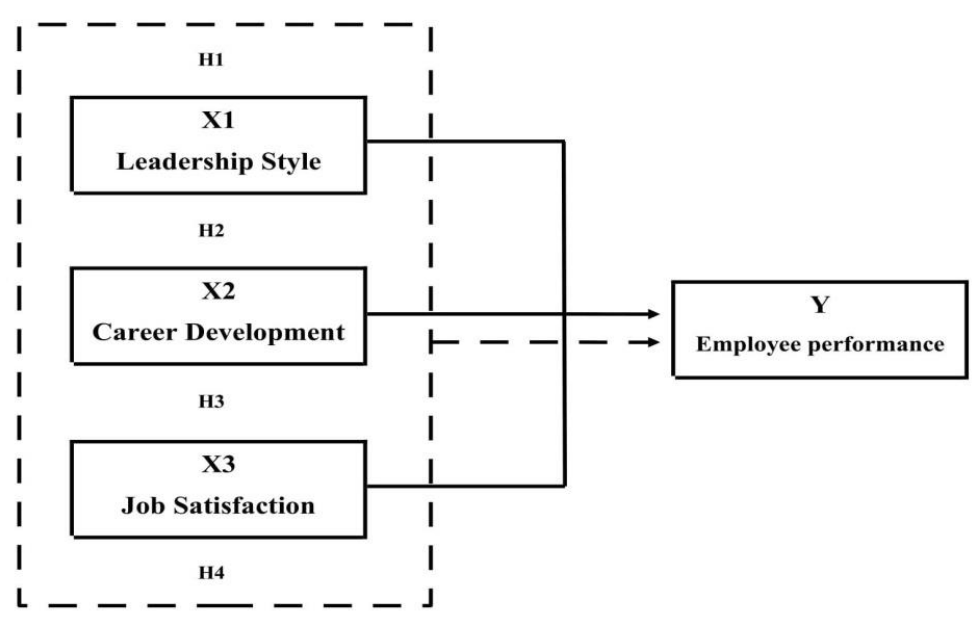

Note

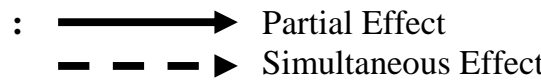

Figure 1 Conceptual framework 


\subsection{Research Hypotheses}

1. H1 : There is a significant influence of leadership style on the performance of TDC Unair employees.

2. H2 : There is a significant influence on career development on the performance of TDC Unair employees.

3. H3 : There is a significant influence of job satisfaction on the performance of TDC Unair employees.

4. H4 : There is an influence of leadership style, development career, and job satisfaction simultaneously have a significant effect.

\section{Methodology}

This research uses descriptive quantitative research methods, the process starts from the theory, then by using logic and derived research hypotheses that are accompanied by measurement and operational concepts, so it can be concluded as research findings. The population that is the object of this study is the Employees of the Tropical Disease Institute Airlangga University Surabaya with a total of 59 employees. Thus in this study using census techniques.

Before entering into the technique of data analysis the instrument testing is done by testing the validity and reliability with the help of SPSS Version 18.0 for windows. The analysis technique in this study uses Multiple Linear Regression. (Sugiyono, 2012) Linear Regression Analysis Multiple is used to interpret how the state (ups and downs) of the dependent variable, if two or more dependent variables as manipulated predictor factors are increased downward value. Multiple Linear Regression is a linear regression model involving more than one independent variable or predictor. This analysis is used to determine whether there is an influence and how the influence of independent variables namely leadership style (X1), career development (X2), and job satisfaction (X3) on employee performance dependent variable (Y).

\section{Result and discussion}

\subsection{Reliability and Validity}

Based on the research shows that the cronbanch alpha value is 0.804 which means that it is above the acceptance limit of 0.6 because of that, the research instrument for the relationship between variables shows good consistency and acceptable data. Based on the research value the correlation index for the relationship between the independent variables (Leadership Style, Career Development, and Job Satisfaction) and the dependent variable (employee performance) is greater than 0.3 and below the significant level of $5 \%(0.05)$. Therefore, data is considered valid.

\subsection{Multiple Linier Regression Result}

Table 1 Multiple Linier Regression Result

Coefficients $^{\mathrm{a}}$

\begin{tabular}{llrrrrr}
\hline Model & \multicolumn{2}{c}{ Unstandardized Coefficients } & \multicolumn{2}{c}{$\begin{array}{c}\text { Standardized } \\
\text { Coefficients }\end{array}$} \\
& B & Std. Error & Beta & t & Sig. \\
\hline $1 \quad$ (Constant) & 12.185 & 4.005 & & 3.042 & 0.004 \\
& Leadership Style & 0.391 & 0.095 & 0.490 & 4.104 & $<0.001$ \\
Career Development & 0.104 & 0.085 & -0.123 & -1.226 & 0.025 \\
& Job Satisfaction & 0.362 & 0.188 & 0.233 & 1.926 & 0.049 \\
\hline
\end{tabular}

a. Dependent Variable: Employee Performance 
From the above equation it means:

1. This constant value of 12.185 shows that if the Leadership Style (X1), Career Development (X2) and Job Satisfaction (X3) are equal to zero, then the Employee Performance is 12.185

2. Leadership Style Value (X1) 0.391 (smaller than 0.05). This shows that if the Leadership Style (X1), it will increase Employee Performance (Y) by 0.391 assuming the amount of other independent variables is constant

3. Career Development coefficient (X2) value is 0.104 (smaller than 0.05). This shows that if Career Development (X2), it will increase Employee Performance (Y) by 0.104 units assuming the amount of other independent variables is constant.

4. The coefficient value of Job Satisfaction (X3) is 0.363 (smaller than 0.05). This shows that if Job Satisfaction (X3), it will increase Employee Performance (Y) by 0.363 units assuming the amount of other independent variables is constant.

\subsection{Result of $R$ Square}

Table 2 Result of R Square

\begin{tabular}{llllll}
\multicolumn{9}{c}{ Model Summary $^{\mathbf{b}}$} \\
\hline Model & & $\mathrm{R}$ & $\mathrm{R}$ Square & Adjusted R Square & Std. Error of the Estimate \\
Dimension 0 & 1 & $0.690^{\mathrm{a}}$ & 0.477 & 0.448 & 1.995
\end{tabular}

a. Predictors: (Constant), Total_X3, Total_X2, Total_X1

b. Dependent Variable: Total_Y

The value of R Square is 0.690 , which means that all independent variables of leadership style, career development and job satisfaction have a positive relationship with employee performance.

\subsection{Test of Classical Asumption}

1) Multicollinearity Results

Table 3 Multicollinearity Results

\begin{tabular}{|c|c|c|c|}
\hline \multicolumn{2}{|c|}{ Model } & \multicolumn{2}{|c|}{ Collinearity Statistics } \\
\hline & & Tolerance & VIF \\
\hline \multirow[t]{4}{*}{1} & (Constant) & & \\
\hline & Leadership Style & $.66 \varepsilon$ & 1.497 \\
\hline & Career Development & .937 & $1.06 i$ \\
\hline & Job Satisfaction & .652 & 1.53 \\
\hline
\end{tabular}

Based on the table above it can be seen that the regression model does not experience multicollinearity disorder. This can be seen from the tolerance value of each independent variable which is more than 0.1. VIF calculation results also show that the VIF value of each independent variable $>10$. So it can be concluded that there is no multicollinearity between independent variables in the regression model. 
2) Heteroscedaticity Test (Scatterplot and Glejser)

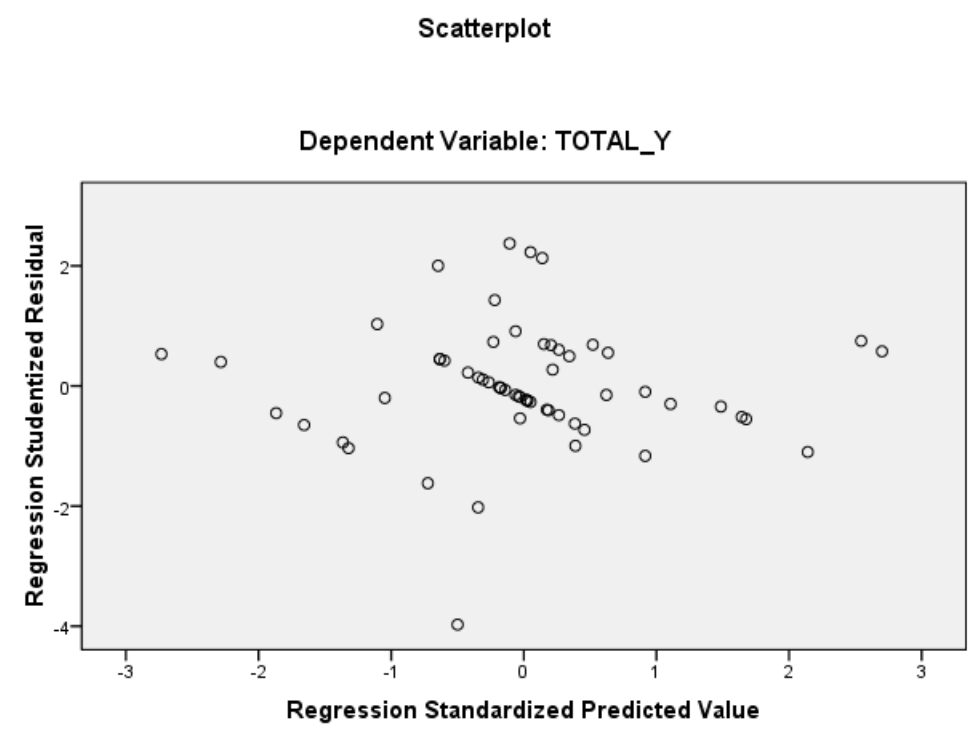

Figure 2 Scatterplot

Herteroscedasticity test results show that there is no specific pattern, not gathering above or below and the points spread above or below or around zero, it can be concluded that there is no heteroscedasticity problem.

Table 4 Glejser Test

Coefficients $^{\mathrm{a}}$

\begin{tabular}{|c|c|c|c|c|c|c|}
\hline \multirow{2}{*}{\multicolumn{2}{|c|}{ Model }} & \multirow{2}{*}{\multicolumn{2}{|c|}{ Unstandardized Coefficients }} & \multirow{2}{*}{\multicolumn{3}{|c|}{$\begin{array}{l}\text { Standardized } \\
\text { Coefficients }\end{array}$}} \\
\hline & & & & & & \\
\hline \multirow[t]{4}{*}{1} & (Constant) & 3.431 & 4.852 & & 0.707 & 0.482 \\
\hline & Leadership Style & 0.028 & 0.127 & 0.031 & 0.220 & 0.826 \\
\hline & Career Development & -0.035 & 0.081 & -0.062 & -0.430 & 0.669 \\
\hline & Job Satisfaction & -0.026 & 0.089 & 0.043 & -0.293 & 0.771 \\
\hline
\end{tabular}

a. Dependent Variable: Employee Performance

Heteroscedasticity test results with the Glajser method obtained significance value of Leadership Style (X1) of 0.826 $>0.05$, the significance value of Career Development (X2) of $0.669>0.05$ and the significance value of Job Satisfaction $(\mathrm{X} 3)$ of $0.771>0.05$, then it can be concluded that there is no heteroscedasticity problem.

\section{3) Normality}

Based on the picture above shows that the points - gathered around the diagonal line, it can be said that this study is normally distributed. 


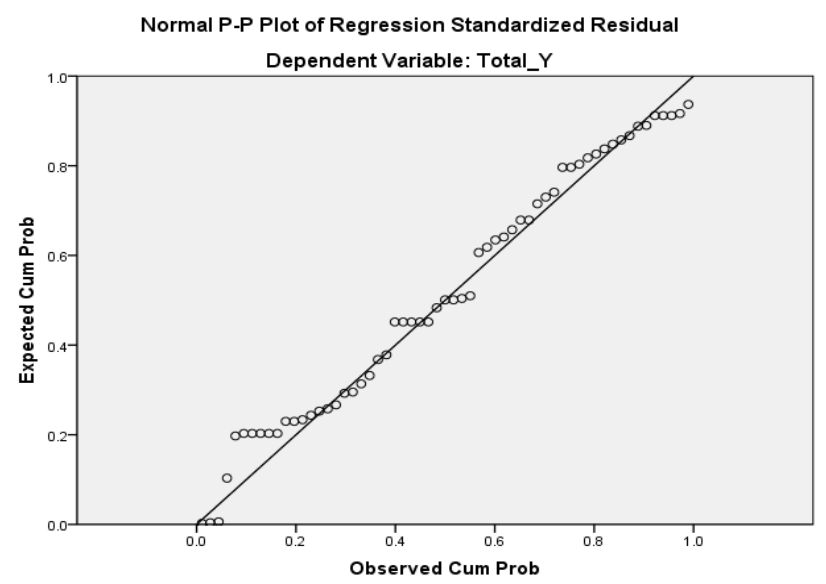

Figure 3 P-P Plot

\subsection{Hypothesis Testing}

1) F-Test

Table 5 ANOVA Test

\begin{tabular}{llcrrrr}
\multicolumn{7}{c}{ ANOVA $^{\mathbf{b}}$} \\
Model & & Sum of Squares & df & Mean Square & F & Sig. \\
\hline 1 & Regression & 199.423 & 3 & 66.474 & 16.703 & $0.000^{\mathbf{a}}$ \\
& Residual & 218.882 & 55 & 3.980 & & \\
& Total & 418.305 & 58 & & & \\
\end{tabular}

a. Predictors: (Constant), Job Satisfaction, Career Development, Leadership Style

b. Dependent Variable: Employee Performance

The calculated $\mathrm{F}$ value obtained for 16.703 is greater than the $\mathrm{F}$ table 2.00. This means that the variables of Leadership Style (X1), Career Development (X2) and Job Satisfaction (X3) simultaneously have a significant effect on Employee Performance (Y).

2) T-Test

Table 6 T Test

Coefficients $^{\mathrm{a}}$

\begin{tabular}{|c|c|c|c|c|c|c|}
\hline \multicolumn{2}{|c|}{ Model } & \multicolumn{2}{|c|}{ Unstandardized Coefficients } & $\begin{array}{c}\text { Standardized } \\
\text { Coefficients }\end{array}$ & $\mathrm{t}$ & Sig. \\
\hline \multirow[t]{4}{*}{1} & (Constant) & 12.185 & 4.005 & & 3.042 & 0.004 \\
\hline & Leadership Style & 0.391 & 0.095 & 0.490 & 4.104 & $<0.001$ \\
\hline & Career Development & 0.104 & 0.085 & -0.123 & -1.226 & 0.025 \\
\hline & Job Satisfaction & 0.362 & 0.188 & 0.233 & 1.926 & 0.049 \\
\hline
\end{tabular}

a. Dependent Variable: Employee Performance

1. The influence of leadership style variables (X1) on employee performance (Y) The results of the analysis of Career Development variables (X1) obtained a significant value of 0,000 (less than 0.05) which means the work discipline variable (X1) has a significant influence on employee performance (Y). 
2. Effect of Career Development variable (X2) on Employee Performance (Y) The results of the analysis of organizational culture variables (X2) obtained a significant value of 0.025 (smaller than 0.05 ) which means that organizational culture variables (X2) have a significant influence on employee performance (Y).

3. Effect of Job Satisfaction variable (X3) on employee performance (Y) The results of the Job Satisfaction variable analysis (X3) obtained a significant value of 0.049 (less than 0.05 ) which means the compensation variable (X3) has a significant influence on employee performance ( Y).

\section{Conclusion}

Based on the results of data analysis of leadership style, career development, and job satisfaction on employee performance, the author gets data from respondents as many as 59 questionnaires that have been processed using Microsoft Excel 2013 and SPSS 18 applications and the author gets the following conclusions:

1. Leadership Style has a positive effect on Employee Performance.

2. Career Development has a positive effect on employee performance

3. Job Satisfaction has a positive effect on Employee Performance.

4. Leadership Style, Career Development, and Job Satisfaction simultaneously influence employee performance.

\section{Recommendation}

Based on the research results obtained stating that the Leadership Style, Career Development, and Job Satisfaction have a positive effect on Employee Performance, the authors wish to submit suggestions to the Institute of Tropical Diseases, Airlangga University, Surabaya, which can be used as a consideration in improving employee performance. To improve the Leadership Style in the Institute of Tropical Diseases, Airlangga University, leaders need to improve leadership style variable items based on the results of this study can still be optimized. Suggestions from the author are the Institute of Tropical Diseases Airlangga University can conduct an evaluation to be able to optimize in terms of leadership style.

For career development in order to meet employee expectations regarding the clarity of career development plans for the employees themselves, the company should prepare a career development plan well for employees so that employees will feel clear of career plans in the Tropical Institute of Airlangga University

\section{Reference}

Ardana, I. K., Mujiatai, N. W., \& Utama, I. W. M. (2012). Pengembangan Karir. In Manajumen Sumber Daya Manusia. Graha Ilmu.

Badriyah, M. (2013). Sumber Daya Manusia. In Manajemen Sumber Daya Manusia. Pustaka Setia Bandung.

Badriyah, M. (2015a). Kepuasan Kerja. In Manajemen Sumber Daya Manusia (Cetakan Ke). Pustaka Setia Bandung.

Badriyah, M. (2015b). Manajemen Sumber Saya Manusia. Kepuasan Kerja, 227-228.

Sugiyono. (2012). Regresi Linier Berganda. In Metode Penelitian Kuantitatif, Kualitatif, dan R\&D (p. 277). Alfabeta. Thoha, M. (2010). Gaya Kepemimpinan. In Kepemimpinan Dalam Manajemen (p. 49). Rajagrafindo Persada. 